\title{
PEDIATRIC NURSES' PERCEPTION AND PRACTICES REGARDING NEONATAL DISCHARGE FROM NEONATAL INTENSIVE CARE UNITS
}

\author{
Amal Ahmed Khalil ${ }^{1}$, Mona Ibrahim Abou Zeid ${ }^{2}$, SinaaAbd El Fattah Khattab ${ }^{3}$ \\ Professor of Pediatric Nursing ${ }^{1}$, Assistant Professor of Pediatric Nursing ${ }^{2}$,Master \\ Degree of Pediatric Nursing ${ }^{3}$ \\ Faculty of Nursing, Port Said University ${ }^{1,2,3}$
}

\begin{abstract}
Background: Today's, the neonatal discharge planning care has been an indispensable component of neonatal intensive care. However, this comes with various challenges. So, pediatric nurses must be able to provide effective nursing care and to be awareof their roles, to achieve successful discharge of baby from Neonatal Intensive Care Unit.Aim: to assess pediatric nurses'perception and practices regarding neonatal discharge from Neonatal Intensive Care Units. Study Design: a descriptive design was utilized in this study. Setting:The study wascarried out in NeonatalIntensive Care Units, at general hospitals in Port-Said Governorate, Egypt.Subjects andMethod: Sixty pediatricnurseswere included in the present study. Data were collected using NICU discharge practices questionnaire, andNICU discharge perception scale. Results: Themain finding of thisstudy revealed that all pediatric nurses hadpoor neonatal discharge practices, while the majority of them had good perception regarding neonatal discharge.Conclusion: There waspositive statistical significant correlation between pediatric nurses' practices andtheir perception regarding neonatal discharge. Recommendation:Continuous trainingprogramwas recommended for pediatric nurses to enhance their perception and improve their skills toward neonatal discharge.
\end{abstract}

Keywords: Discharge planning, Discharge process, Discharge care, Discharge practices, Discharge perception, Pediatric nurse, Neonatal Intensive Care Unit (NICU) 


\section{INTRODUCTION}

Discharge planning which is defined as"the activities that facilitate a pediatric patient's movement from one health care setting to another, or to home", it is a multidisciplinary process involving physicians, pediatric nurses, social workers, and other health professionals. It is a key concept in the delivery of pediatric nursing care. However, discharge planning has emerged as the complex areas of practice, and the most important one of these areas is the Neonatal Intensive Care Units (NICUs), to enhance continuity of care for new born babies(Perry, 2017; Watts \& Gardner, 2005).

Berryet al (2014) appointed that discharge care begins at admission and continues on subsequent days before the day of discharge. Moreover, Care and discharge (DC) planning in the NICUs vary according to: firstly, leadership styles and competencies; secondly, the knowledge base of pediatric nursing and medical staff; thirdly, the systems which support the work of physicians, pediatric nurses, and support staff; fourthly, the policies, regulations, and laws that dictate scope of practices for physicians, pediatric nurses, and support staff; and finally, the nature of the physical facility. Despite these factors, there is a core set of practices that characterize DC. In general, DC planning can be characterized on a continuum according to the needs of the neonates(Lovejoy-Bluem, 2014).

Pediatric nurses play a critical role in neonatal discharge from NICU to home care giver, hand of care for high risk newborns, and sick babies during the staying period in NICU to the day of discharge, and after hospitalization is a dangerous time(Lopez, Anderson, \&Feutchinger, 2012).

A neonatal nurse is professional with special training, skills, and knowledge in the care of newborns and their families(Enzman,Hagedorn, \& Gardner, 1999). The Newborn admission to NICU requires specialized skillful pediatric nurses in order to not only assess the newborn biological features, but also focus care on both Newborn and his parents (Ribeiro et al., 2015).

The pediatric nurse who is one of the multidisciplinary team has daily rounds on every neonate in NICU, to determine the degree of medical,psychosocial,environmental and financial readiness of the neonate to go home, and what is holding up the discharge to take the appropriate action. Also, the team has weekly meetings to provide opportunities for discussing the risks which face the neonate and the family's perspective at home. The pediatric nurses assess the 
babies several times a day for physiological stability, and feeding readiness, to determine if they are ready to move according to the clinical protocol(Manag, 2015\&Purdy et al., 2015).

It is important for the neonatal nurses and other members of health care team toknow what the newborn's parents truly experience during their neonate hospital staying period at NICU(Ribeiro, Moura, Sequeira, Barbieri, \& Erdmann, 2015). Sensitivity to neonatal mothers' needs is depend on the perception of pediatric nurses which are "the ability to become aware of something through seeing and hearing senses and priorities held by the parents and NICU nurses", So, the neonatal nurses and other health care team get parent involved in daily care of their baby and give them hands-on experience. This in turn, makes parents not to be anxious about caring for the neonate at home (Heidari et,al., 2015).

Neonatal nurses improve the quality of discharge care by listening to neonates' parents, and are aware of what difficulties can face the baby and the parents at home. The neonatal nurse teaching can be tailored to meet the specific neonatal needs, as well as, common problems encountered by many high risk infants and their parents. (Scherf, 2006).So, supporting and involving parents in the discharge process from NICU is vital importance as it can reduce the risk of readmission and also give the parents' confidence in caring for their newborn infant at home(Loughren, 2012).Parents are expected to assume full responsibility for their child's care including feeding, administering medication, preventing of infection, or providing developmental issues(Mancini\&While, 2001).

\section{Significance of the study:}

In NICUs, pediatric nurses play a vital role in neonatal successful discharge to their parents as primary caregivers. Furthermore, observer, knowledgeable, and skillful pediatric nurses can centered their discharge nursing care practices and perception to avoid or reduce readmissions of the neonate and decrease health carecost (Profit, 2011).

As a result of increase infants discharge from NICUs with unresolved health care issues, ongoing technology needs, absence of well-planned discharge of medically stable infant to home, minimize avoidable hospital readmissions(Hummel 
\& Cronin, 2005), and the importance of studying pediatric nurses' perception and practices regarding new born discharge from NICUs, this study was designed tomeet pediatric nurses' needs of discharge caring for both neonates and their parents to provide high quality nursing care regarding neonatal discharge.

\section{AIM OF THE STUDY}

\section{The aim of thepresent study is:}

To assess pediatric nurses' perception and practices regarding neonatal discharge from Neonatal Intensive Care Units

\section{The present study objectives:}

1- Assess nurses' perception regarding newborn discharge from Neonatal Intensive Care Units.

2- Assess nurses' practices regarding newborn discharge from Neonatal intensive Care Units.

\section{Operational Definition of Discharge Practices:}

The concept of discharge practices of pediatric nurses referred to the preparation activities which provided for neonates in NICUs regarding discharge as feeding readiness, physiological stability, parental engagement and education that begins at admission and continues beyond neonatal discharge(Purdy, Craig, \& Zeanah, 2015; Jefferies, 2014).

\section{SUBJECTS AND METHOD}

\section{Research Design:}

A descriptive design was used for the current study.

\section{Setting:}

The study was conducted in Neonatal Intensive Care Units (NICUs) at governmental hospitals namely; Port-Fouad General Hospital, El-Nasr Hospital, Obstetrics and Gynecology Hospital, and Port-Said General Hospital. 


\section{Subjects:}

A sample of the present study consisted of all pediatric nurses working in NICUs (60 pediatric nurses). The sample was selected on the basis of convenience sampling techniquefromprevious mentioned settings.

\section{TOOLS FOR DATA COLLECTION:}

Two tools were used to collect data for this study:

\section{Tool (1): The NICU Discharge Reported Practices Questionnaire:}

This questionnaire was developed in English language by Lovejoy-Bluem (2014)and Jefferies (2014).It measures nurses' reported practices regarding neonatal discharge from NICUs. It includes 25 questions. Translation into Arabic language, and modification of the tool were done by the researcher. It divided into two parts:

Part 1: It includes personal characteristics of pediatric nursesas educational level, occupational position and years of experience. It showed that all studied nurses in this study were females(100\%), the majority of them were staff nurses $(88.3 \%)$.Around half of pediatric nurses $(56.7 \%)$ had technical institute, followed by $26.7 \%$ of them had nursing bachelor. $71.7 \%$ of them had experience years less than five years, and few percentage $(15 \%)$ had experience years more than 10 years in pediatric nursing field.

Part 2:This part included 25 questions to assess nurses' reported practices ; it consisted of nine dimensions of nurses reported practices namely:Composition and frequency of interdisciplinary DC meeting, Discharge criteria, Parental involvement with baby care, Parental participation in DC planning, Preparation for post-discharge care, Providing discharge summary to primary care providers, Evaluating the respondents to achieve the successful discharge and reduce the re-hospitalization, Teaching discharge instruction to parent, and Methods to evaluating discharge planning. 
Scoring System: NICU discharge reported practices responses of studied nurses were calculated as the following:

- The studied nurses' answers were compared with two keysof model answers.

- Two scoreswere given for complete correct answer, one score for incomplete correct answer, and 0score for incorrect answer for each response of pediatric nurses regarding only ten questionsof NICU discharge reported practices questionnaire, namely; 1,3,6,7,8,9,10,11,12,14.

- Regarding the reminder of questions of NICU discharge reported practices questionnaire (15 questions), allresponses of studied nurses' reported practices were considered correct answers, and measured on two points: applicable (one score) and not applicable ( 0 score) to all responses of these questions $(2,4,5,13,15,16,17,18,19,20,21,22,23,24,25)$. The scores of the questions were summed up and the total (83) was divided by numbers of items (25), giving a mean score. These scores were converted into a percentage score. The pediatric nurse's reported practices of each subject was considered good if percentage score was equal or more than $75.0 \%$,average if percentage score was $60.0 \%$ to less than $75.0 \%$ and poor if percentage score was less than $60.0 \%$ (Abdel Khalek, 2016).

\section{Tool (2):NICU Discharge perception scale:}

This scale was developed in English language by Lalani and Gulzar (2001)and Lingle (2013).It used to assess the perception of pediatric nurses regarding neonatal discharge from NICUs. It consisted of 22 items.Translation into Arabic language and modification were done by the researcher. The scale includedthree dimensions of pediatric nurses' perception namely;Parent teaching about neonatal discharge care, Factors affecting neonatal discharge care, and Nursing role in discharge planning.The pediatric nurses' responses regarding NICU Discharge perceptionwere measured on three pointsLikertscale; "agree”, “don't know” and "disagree”.

Scoring System:NICU discharge perception of studied nurses was calculated as the following: Three scores for agree response, two scores for don't know and one score for disagree response, and reversed for negative items.The scores of all items of NICU Discharge perception were summed up, and the total (66) was divided by 
numbers of items (22), giving a mean score. These scores were converted into a percentage score. The pediatric nurse's perception of each subject was considered good if percentage score was equal or more than $75.0 \%$, average if percentage score was $60.0 \%$ to less than $75.0 \%$ and poor if percentage score was less than $60.0 \%$ (Abdel Khalek, 2016).

\section{Validity}

The two tools used in the present study were tested for content validity by jury of five experts in the field of pediatric nursing,from the Faculty of Nursing in Port Said governorate, and accordingly the necessary modifications were done based on their opinions.

\section{Reliability}

Cronbach alpha coefficientwas calculated to assess the reliability for tool one and two of the present study; its values were 0.76 , and 0.68 respectively.

\section{Pilot study}

A pilot study was undertaken before starting the data collection phase. It was carried out on six pediatric nurses in NICUs, who represent approximately $10 \%$ of the total sample size, and they were included in the main study sample. The purpose of the pilot study was to test the applicability and the feasibility of the study tools before beginning the data collection phase, and estimate the time needed to complete the tools. It also helped to find out any obstacles and problems that might interfere with data collection.

\section{Field Work:}

Before starting any step in the study, an official letter was issued from the Dean of the Faculty of Nursing, Port Said University to the directors of the mentioned hospitals in the previous settings, requesting their cooperation and permission to conduct the study at the Neonatal Intensive Care Units in these hospitals. The study was conducted using the tools of the present study, which was conducted on an individual basis. The researcher started to collect data for two days per week. Each tool lasted 25-35minutes to be completed, depending on the response of the 
participant. The process of data collection took a period of three months from the first of October 2018 to 31December 2018.

\section{Ethical Considerations:}

Hospital permission was taken to hold out the current study. An oral consent was obtained from pediatricnurses to participate in the study. The aim of the study was explained for each pediatric nurse. Respect for privacy of each participant in the study. In all settings of the study, each participant was assured that the information obtained for the study was confidential and used only for the aim of the present research. Moreover, ensure that all participants have the right to withdraw from the study at any time.

\section{StatisticalAnalysis}

Collected data were coded, computed and statistically analyzed using statistical package of social sciences (SPSS 16).Data were presentedusing descriptive statistics in the form of frequencies and percentages for qualitative variables, and means and standard deviations for quantitative variables. $t$ test was used for comparison of data between two groups, and ANOVATest $(\mathrm{F})$ was used to compare the data of more than two groups. Statistical significance was considered at P-value $<0.05$.

\section{RESULTS:}

Table (1): showsthe personal characteristics of the studied nurses, regarding their educational level, occupational position, gender, and experience years in pediatric nursing field. It was revealed that all studied nurses were female (100\%), the majority of them were staff nurses $(88.3 \%)$.Around half of studied nurses $(56.7 \%)$ had technical institute, followed by $26.7 \%$ of them had nursing bachelor. $71.7 \%$ of them had experience years less than five years, and few percentage (15\%) had experience years more than 10 years in pediatric nursing field.

Table (2): Shows that more than three quarters (76.7\%) of studied nurses had good practices toward evaluating the respondents to achieve the successful discharge and reduce the re-hospitalization, followed by more than half of them $(58.4 \%)$ had good practice inneonatal discharge criteria. It was evidenced that $100 \%$ of studied nurses had poor practices toward neonatal discharge regarding parental participation in DC 
planning, providing discharge summary to primary care providers, parental involvement with baby care,methods to evaluate discharge planning,teaching discharge instructions to parent, preparation for post discharge care and composition and frequency of interdisciplinary DC meeting (100\%,98.3\%,96.6\%, 88.3\% 78..3\%, $56.7 \%$, and $63.3 \%$ respectively).

Table (3): illustrates thatthe most of studied nurses had good perception regarding neonatal discharge inNICUs (80\%), includingnursing role in discharge planning and factors affecting discharge care (90\%, and $85.0 \%$ respectively), while more than two fifths $(48.3 \%)$ of studied nurses had average level of perception regarding parent teaching about neonatal discharge.

Table (4) represents the relation between total NICU discharge practices of pediatric nurses and theirpersonal characteristics. The current research findings were found that there were no statistical significant relations betweentotal NICU discharge practices of pediatric nurses and theirpersonal characteristics including educational level, occupational position, and experience years in pediatric nursing field $(\mathrm{P}=0.626$, $\mathrm{P}=0.531$, andP $=0.266$ respectively).

The relation between total NICU discharge perception of pediatric nurses and theirpersonal characteristics was revealed inTable 5. Statistically significant relations betweentotal NICU discharge perception of pediatric nurses and theirpersonal characteristics including educational level, occupational position, and experience years in pediatric nursing field were not found $(\mathrm{P}=0.196, \mathrm{P}=0.212$, andP $=0.660$ respectively).

Table (6): shows the correlation between total NICU discharge practices and perception scores of the studied nurses.Pediatric nurses'total NICU discharge practiceswere positivelycorrelated with theirperception of NICU discharge $(r=0.347)$. The correlation wasstatistically significant $(\mathrm{p}$-value $=0.007)$, which means thatwhen the pediatric nurses NICU discharge perception increase, their NICU discharge practices increase too andvice versa. 
Table (1): Personal Characteristics of the Studied Nurses $(n=60)$

\begin{tabular}{|l|c|c|}
\hline personal Characteristics & $\begin{array}{c}\text { Frequency } \\
\text { No }\end{array}$ & $\begin{array}{c}\text { Percent } \\
\text { \% }\end{array}$ \\
\hline Educational level & 10 & 16.7 \\
-Nursing Diploma & 34 & 56.7 \\
-Technical institute & 16 & 26.7 \\
-Nursing Bachelors & 53 & \\
\hline Occupational position- & 7 & 88.3 \\
Staffnurse & & 11.7 \\
-Head nurse & 60 & \\
& 0 & 100.0 \\
Gender & & 0.0 \\
-Female & 43 & 71.7 \\
-Male & 8 & 13.3 \\
\hline Experience years & 9 & 15.0 \\
-<5 years & & \\
-5 - 10 years & & \\
->10 years & & \\
\hline
\end{tabular}

Table (2): Total Pediatric Nurses' Neonatal Intensive Care Unit Discharge Practices

Dimensions $(n=60)$

\begin{tabular}{|l|c|c|c|c|c|c|}
\hline \multirow{2}{*}{ Dimensions } & \multicolumn{2}{|c|}{ Poor } & \multicolumn{2}{c|}{ Average } & \multicolumn{2}{c|}{ Good } \\
\cline { 2 - 7 } & $\mathbf{N}$ & $\mathbf{( \% )}$ & $\mathbf{N}$ & $\mathbf{( \% )}$ & $\mathbf{N}$ & $\mathbf{\%})$ \\
\hline $\begin{array}{l}\text { Composition and frequency of } \\
\text { interdisciplinary discharge } \\
\text { meeting }\end{array}$ & 38 & 63.3 & 8 & 13.3 & 14 & 23.4 \\
\hline Discharge criteria & 23 & 38.3 & 2 & 3.3 & 35 & 58.4 \\
\hline $\begin{array}{l}\text { Parental involvement with baby } \\
\text { care }\end{array}$ & 58 & 96.6 & 1 & 1.7 & 1 & 1.7 \\
\hline $\begin{array}{l}\text { Parental participation in discharge } \\
\text { planning }\end{array}$ & 60 & 100 & 0 & 0 & 0 & 0 \\
\hline $\begin{array}{l}\text { Preparation for post-discharge } \\
\text { care }\end{array}$ & 34 & 56.7 & 15 & 25 & 11 & 18.3 \\
\hline $\begin{array}{l}\text { Providing discharge summary to } \\
\text { primary care providers }\end{array}$ & 59 & 98.3 & 1 & 1.7 & 0 & 0 \\
\hline $\begin{array}{l}\text { Evaluating the respondents to } \\
\text { achieve the successful discharge } \\
\text { and reduce the re-hospitalization }\end{array}$ & 2 & 3.3 & 12 & 20 & 46 & 76.7 \\
\hline $\begin{array}{l}\text { Teaching discharge instructions to } \\
\text { parent }\end{array}$ & 47 & 78.3 & 8 & 13.3 & 5 & 8.4 \\
\hline $\begin{array}{l}\text { Methods to evaluate discharge } \\
\text { planning }\end{array}$ & 53 & 88.3 & 7 & 11.7 & 0 & 0 \\
\hline $\begin{array}{l}\text { Overall pediatric nurses' NICU } \\
\text { discharge practices }\end{array}$ & $\mathbf{6 0}$ & $\mathbf{1 0 0}$ & $\mathbf{0}$ & $\mathbf{0 0}$ & $\mathbf{0}$ & $\mathbf{0 0}$ \\
\hline
\end{tabular}


Table (3): Total Pediatric Nurses' NICU Discharge Perception Dimensions ( $n=60)$

\begin{tabular}{|c|c|c|c|c|c|c|}
\hline \multirow{2}{*}{$\begin{array}{l}\text { Perception } \\
\text { Dimensions }\end{array}$} & \multicolumn{2}{|c|}{ Good } & \multicolumn{2}{c|}{ Average } & \multicolumn{2}{c|}{ Poor } \\
\cline { 2 - 7 } & No & $\%$ & No & $\%$ & No & $\%$ \\
\hline 1-Parent teaching & 10 & 16.7 & 29 & 48.3 & 21 & 35 \\
\hline $\begin{array}{c}\text { 2-Factors affecting } \\
\text { discharge care }\end{array}$ & 51 & 85.0 & 6 & 10 & 3 & 5 \\
\hline $\begin{array}{c}\text { 3-Nursing role in } \\
\text { discharge planning }\end{array}$ & 54 & 90 & 5 & 8.3 & 1 & 1.7 \\
\hline $\begin{array}{c}\text { Overall pediatric } \\
\text { nurses' NICU } \\
\text { discharge } \\
\text { perception }\end{array}$ & 48 & 80.0 & 12 & 20 & 0.00 & 0.00 \\
\hline
\end{tabular}

Table (4): Relation between Pediatric Nurses' Personal Characteristics and TotalNICU Discharge Practices $(n=60)$

\begin{tabular}{|c|c|c|c|c|}
\hline \multirow[t]{2}{*}{ Personal Characteristics } & \multirow[t]{2}{*}{ No } & \multirow[t]{2}{*}{$\%$} & \multicolumn{2}{|c|}{$\begin{array}{c}\text { TotalNICU Discharge } \\
\text { Practices }\end{array}$} \\
\hline & & & Test & P-value \\
\hline $\begin{array}{l}\text { Educational levelDiploma } \\
\text { Institute } \\
\text { Bachelor }\end{array}$ & $\begin{array}{l}10 \\
34 \\
16\end{array}$ & $\begin{array}{l}16.7 \\
56.7 \\
26.7\end{array}$ & $\begin{array}{c}F= \\
0.473\end{array}$ & 0.626 \\
\hline $\begin{array}{l}\text { Occupational position Staff } \\
\text { nurse } \\
\text { Head nurse }\end{array}$ & $\begin{array}{c}53 \\
7\end{array}$ & $\begin{array}{l}88.3 \\
11.7\end{array}$ & $\begin{array}{c}T= \\
0.630\end{array}$ & 0.531 \\
\hline $\begin{array}{l}\text { Experience years } \\
<5 \text { years } \\
5-10 \text { years } \\
>10 \text { years }\end{array}$ & $\begin{array}{r}43 \\
8 \\
9\end{array}$ & $\begin{array}{l}71.7 \\
13.3 \\
15.0\end{array}$ & $\begin{array}{c}F= \\
1.354\end{array}$ & 0.266 \\
\hline
\end{tabular}


Table (5): Relation between Pediatric Nurses' Personal Characteristics and TotalNICU Discharge Perception $(n=60)$

\begin{tabular}{|c|c|c|c|c|}
\hline \multirow[t]{2}{*}{ Personal Characteristics } & \multirow[t]{2}{*}{ No } & \multirow[t]{2}{*}{$\%$} & \multicolumn{2}{|c|}{$\begin{array}{c}\text { TotalNICU Discharge } \\
\text { Perception }\end{array}$} \\
\hline & & & Test & P-value \\
\hline \multicolumn{5}{|l|}{ Educational level } \\
\hline Diploma & 10 & 16.7 & $\mathbf{F}=$ & \multirow{3}{*}{0.196} \\
\hline Institute & 34 & 56.7 & 0.473 & \\
\hline Bachelor & 16 & 26.7 & & \\
\hline \multicolumn{5}{|l|}{ Occupational position } \\
\hline Staffnurse & 53 & 88.3 & $1=$ & \multirow[t]{2}{*}{0.212} \\
\hline Head nurse & 7 & 11.7 & & \\
\hline \multicolumn{5}{|l|}{ Experience years } \\
\hline$<5$ years & 43 & 71.7 & $\mathbf{F}=$ & \multirow{3}{*}{0.660} \\
\hline $5-10$ years & 8 & 13.3 & 1.354 & \\
\hline$>10$ years & 9 & 15.0 & & \\
\hline
\end{tabular}

Table (6): Correlation between Total NICU Discharge Practices and Perception Scores of the Studied Nurses ( $n=60)$.

\begin{tabular}{|l|c|c|}
\hline \multirow{2}{*}{ Total Practices } & \multicolumn{2}{|c|}{ Total Perception } \\
\cline { 2 - 3 } & P & R \\
\cline { 2 - 3 } & 0.007 & 0.347 \\
\hline
\end{tabular}

\section{DISCUSSION:}

Hospitals around the globe incorporate discharge planning as a fixed component into their health systems. There are numerous benefits to discharge planning, especially within the neonatal intensive care unit, as it could decrease the risk of the infant being re-admitted, limit the duration of time spent in hospital, and offer families the confidence to take care of their sick infant at home. Moreover, a discharge plan is integral to the action administered with the objective of providing 
the best care for the baby, and reducing cost with maximum efficiency nurses belonging to baby's units, which are crucial to success of the discharge planning process in NICUs (Al Reshidi \& Long, 2016).

Discharge preparation in NICU, is critically important. Even for families with healthy term infants, because poor discharge preparation has worse outcomes for infants and their families. It may causeproblems at home and increase unscheduled health care use. (Smith et al., 2009).

It was evidenced that, the majority of studied nurses in the current research had poor practicestowardneonataldischarge. This may be related to;firstly, the NICUpolicy that regulate the work in it. Secondly, lack of training ofpediatric nurses, and their insufficient knowledge regarding neonatal discharge. Thirdly, nursing shortage, and overloading work in NICUs. Finally, technology usageby pediatric nurses to support and help them in their work in NICUs is inactive. This was confirmed with Al Reshidi \& Long, (2016) that found that the nursing role needs clear guidelines, criteria and process regarding discharge care activities, to increase nurses' commitment to complete their discharge practices.

Regarding composition and frequency of interdisciplinary (DC) meeting, the present study showed that the majority of pediatric nurses reported daily attendance of DC meeting. This may be related to the policy that regulates discharge work at NICUs. This finding was supported with Gonçalves-Bradley et al. (2016)who emphasized that discharge planning meeting should be held no less than 24 hours prior to the proposed discharge, and ideally 48 hours. Moreover, the DCmeeting coordinated by the nurse, team manager and social workers, which confirmed with present study, that found more than half of the studied nurse reported high risk follow- up physician and nurse were the most professional health members' attendance in the DC meeting. This may referred to their skillful, competent, and more awareness of neonatal cases and their progresses. Also, a few percentage of discharge coordinator planner nurses were attended the DC meeting. This may be referred to the nurses'role as discharge coordinator planner in the NICUs wasinactivated, and the limited participation in decision making due to NICUs'policies.These results were disagreed with finding ofPurdy et al. (2015)who 
found that the majority of pediatric nurses stressed weekly NICU multidisciplinary DC team meetings to provide opportunities for discussing neonatal discharge reports.

Regarding discharge criteria practicethat must be met before neonatal discharge,the current study showed that the majority of studied nurses had good practice level in this dimension. This may be due to their well trained and sufficient knowledge regarding neonatal discharge criteria practice. This finding agreed with Lovejoy-Bluem (2014)who found that the Academy ofPediatrics recommended AAP guidelines for discharge criteria for DC of high-risk infant which implemented by pediatric nurses as feeding, weight, thermal, and competent home caregiver criteria.

The engagement of parents in care at NICU is crucial,that consequently leads to good health outcomes in discharged neonates. It assists with infant care from the beginning of the NICU stay rooming in, and develops parents' confidence/ competence(Lovejoy-Bluem, 2014). The present study showed that the pediatric nurses had poor practice regarding parental involvement with baby care. Only three fifths of pediatric nurses reported mother'sengagement in kangaroo care in the NICU bedside. Additionally, more than half of studied nurses reported that rooming in wasnot applicable practice, that may related toNICUs'polices which responsible for NICU preparation, to implement these practices; as rooming- in, and the kangaroo care. In addition to, time shortage due to over loading work of pediatric nurses; make therapeutic communication difficult jobwith parents. These findingswereinconsistent withRaffray et al (2014) who found that applying the principles of family-centered care in the NICU to encourage parents to participate in their infant's care as promoting kangaroo care, and this in turnlead to increase parental readiness for their infant's discharge.

The finding of present study revealed poor level in parental participation in neonatal DCpractice that the majority of pediatric nurses reported that parent didn't attend in DC meeting. The only way of parental participationin neonatal discharge was the chart/document in the baby's medical record, that may be referred to the polices in the NICUs which restricted the parent to participate in neonatal DC. This finding was inconsistent with results of Gonçalves-Bradley et al. (2016)who found that the parent must be invited in DC meeting to gain more information about baby illness and his progress. In addition, the present study showed that the video on a 
cellular phone or laptop were not use to encourage family members to view their baby or listen to his discharge meeting report. This finding supported of Hampton (2012) who found that technology should be leveraged to support parental engagement processes of neonatal discharge as, video conferencing, Skype, and other similar technologies must become first line strategies to communicate with pediatric nursing staff, families, and primary care providers.

Regarding preparation for post-discharge care, the present study result revealed that, more than half of the studied nurses had good practice regarding preparation for post discharge care. They reported that the NICU provide on -site high-risk follow up and the most of studied nurses reported that after one week, the first appointment was determined to the parents to visit the NICU clinic to follow-up their baby. Also, the present study showed that about half of studied nurses reported that NICU arranging the parent to the primary care practitioner by meeting both of them in the NICU before neonatal DC. This may be related to the physician who present in the NICU is the same pediatric care physician in the NICU clinic. The study disagreed with the result of Klein (2013) who had limits in follow- up contact with primary care practitioner.

Regarding providing discharge summary to primary care providers, the present study showed that the majority of the studied nurses demonstrated that, the discharge summary was provided to the $1^{\text {st }}$ care providers by giving hard copy to parent to bring it with them at first clinic visit, and a few of them illustrated the use of technology methods to provide discharge summary to pediatric care provider. This may be due to pediatric nurses had insufficient knowledge regarding the importance of technology usage activation in NICU to support and help bothpediatric nurses and the neonates' parents. This result is incongruent with the study of Purdy et al. (2015), who recommended that parents should give a discharge folder that includes all teaching handouts, medication sheets, growth charts, supplies, follow-up appointment dates with phone contacts and a copy of discharge summary contact information to primary care pediatrician, and all post discharge specialists should clearly document in the NICU discharge summary, also sharing of information between both the pediatric care provider and subspecialists involved should receive a copy access via the electronic medical records. 
The current study demonstrated the majority of studied nurse emphasized that the most NICU practices that prevent the re-hospitalization of discharged neonates was the correct and healthy feeding .This result supported withBurnham et al. (2013), who found that the parent need information about neonatal feeding concerning discharge, because infant feeding was an important topic for parent during hospitalization. In addition to, the present study showed that,more than three fifths of studied nurses and the most of them said that increase the dialogue time, listen to the parent by the nurse's unit,and involve parentsin the DC meeting can improve good health outcomes, achieve successful discharge and reduce re-hospitalization of discharged neonates.This was supported withAl Reshidi and Tony Long (2016), who found that the improvement of communication process, with the families of neonates, facilitate successful neonatal discharge.

Regarding methods to evaluating neonatal discharge,the surprise finding of the present study indicated that about most of studied nurses reported that parent home visit by pediatric nurses to assess to neonatal DC, andthe use of discharge evaluation of each baby and primary home caregiver post discharge as telephone contact, or home visit, or written the mail of the NICU to the parent were not applicable practice. This may be related to lack of communication methods between the discharge team in NICUs and the parents.Additionally, avoid the technology usage tosupport and help them in this aspect, in spite of the advanced practice of pediatric nurses, the home visit to parent during baby hospitalization and after discharge, as well as telephone follow-up that improve the neonatal outcomes, through care coordination nurse to prevent complication, or re-hospitalization and decrease health care cost(Boykova\& Kenner, 2012).

In the study of Smith et al.(2009) whichconducted onthe pediatric nurses concerning their perception regarding parent teaching about neonatal discharge care at NICU,highlighted the importance of neonatal discharge teaching. In the same line, the present study found that more than two fifths of studied nurses had average level in the total parent teaching perception dimension. This may be related to lack of pediatric nurses' training regarding NICU discharge care and over loading work. This confirmed with Zamazadeh, et al. (2013) who emphasized that there was shortage in mothers'teaching about baby caregiving as nurses didn't provide information regarding their prediction of the progress ofneonatal discharge. 
The present study results found that pediatric nurses havegood level of perception regarding their nursing role andthefactors affecting neonatal discharge care. This result agreed withRaffray et al. (2014), whodemonstrated that the high percentages of pediatric nurses had good level of perception about the factors affecting neonatal discharge care in the NICU. These findingswere inconsistent with the findings of Hoff, et al. (1994) and Lalani(2001) who found a limited understanding regarding the concept of neonatal discharge, and pediatric nurses were often confused about discharge planning and how it could be accomplished.

\section{CONCLUSION:}

Based on the findings of the current study, it was concluded that the pediatric nurses had poor practices and good perception in neonatal discharge care.Pediatric nurses'total NICU discharge practices andtheir perception were positivelycorrelated with statistically significant, which means that when the pediatric nurses NICU discharge perception increase, their NICU discharge practices increase too andvice versa.

\section{RECOMMENDATIONS:}

Based on the findings of the present study, the following recommendations are proposed:

- Continuous training program was recommended for pediatric nurses to enhance their perception and improve their skills toward neonatal discharge care.

- Encourage managers of general hospitals to modify NICU policies to facilitatepediatric nurses' role in implementinghigh quality neonatal discharge practices.

- Establish educational program for parentsto increase their understandingregarding neonatal discharge care.

- Activate technology usage as telephone follow-up, and videoconferencing services as one strategy for helping parents to participate in baby care and discharge meeting in NICU, and .maintaining continuity with families post discharge. 


\section{REFERENCES:}

Abdel Khalek,Walia. (2016). Impact of an Educational Program on Nurse's Knowledge and Practice Regarding Neonatal Jaundice. Port Said Scientific Journal of Nursing, 3(1), 74-85.

Al Reshidi,Nahar.\& Long, Tony. (2016). Factors influencing discharge planning in neonatal intensive care units in Saudi Arabia: a systematic review.5(1), 27-35.

Berry, Blaine, Rogers, McBride, Schor, Birmingham, et al. (2014). A Framework of Pediatric Hospital Discharge Care Informed by Legislation, Research, and Practice. JAMA Pediatrics, 168(10), 955.

Burnham, Feeley, \& Sherrard. (2013). Parents' Perceptions Regarding Readiness for Their Infant's Discharge from the NICU. Neonatal Network, 32(5), 324-334.

Boykova, \& Kenner. (2012). Transition From Hospital to Home for Parents of Preterm Infants. The Journal of Perinatal \& Neonatal Nursing, 26(1), 81-87.

Enzman Hagedorn, \& Gardner. (1999). Legal Issues in Neonatal Nursing: Considerations for Staff Nurses Advanced Practice Nurses. Journal of Obstetric, Gynecologic \& Neonatal Nursing, 28(3), 320-330.

Gonçalves-Bradley, Lannin, Clemson, Cameron, \& Shepperd. (2016). Discharge planning from hospital. Cochrane Database of Systematic Reviews(1).

Heidari, Haydeh. \& Hasanpour, \& Fooladi. (2015). An exploration of the viewpoints of parents and nurses on care provision in neonatal intensive care units.6(4), 30-36.Iranian Journal of Neonatolog .

Hummel, \& Cronin. (2004).Home care of high risk infant. Advances in Neonatal Care, 4(6), 354 -364.

Hampton,T.(2012).Recent advances in mobile technology benefit global health,research and care.Journal of the American Medical Association,307(19) 
Hoff. (1994).Discharge planning :A study of nursing staff involvement.Journal of Nursing Aministration,24(4),45-50

Jefferies. (2014). Going home: Facilitating discharge of the preterm infant. Paediatrics \& Child Health, 19(1), 31-36.

Klein. (2012). A Pilot Project to Improve Neonatal Peripheral Intravenous Site Assessment and Documentation. Journal of Obstetric, Gynecologic, \& Neonatal Nursing, 41(s1), S31-S31.

Lalani, \& Gulzar. (2001). Nurses' role in patients' discharge planning at the AGA KHAN university hospital ,Pakistan.Journal for Nurses in Staff Development (JNSD), 17(6), 314-319.

Lingle. (2013). Evidence Based Practice: Patient Discharge Education Barriers to Patient Education.

Lopez, Anderson, \& Feutchinger. (2012). Transition of Premature Infants From Hospital to Home Life. Neonatal Network, 31(4), 207-214.

Loughren. (2012). Discharge Planning in the Neonatal Intensive Care Unit. Journal of Obstetric, Gynecologic \& Neonatal Nursing, 41, S54.

Lovejoy-Bluem. (2014). Neonatal Intensive Care Unit Discharge Transitioning: Nursing Practices, Perspectives, and Perceptions. Brandman University.

Manag. (2015). Hospital cuts length of stay for babies in the NICU by four days. Hosp Case Manag, 23(4), 49-50.

Mancini, \& White. (2001). Discharge planning from a neonatal unit: an exploratory study of parents' views.7(1), 59-62.

Purdy, Craig, \& Zeanah. (2015). NICU discharge planning and beyond: recommendations for parent psychosocial support. Journal of Perinatology, 35(S1), S24-S28. 
Profit Jochen, McCormick Marie, Escobar Gabriel, et al. (2011). Neonatal Intensive Care Unit Census Influences Discharge of Moderately Preterm Infants. PEDIATRICS Author manuscript, available in PMC, 119(2), 314-319.

Potter Amy, Hanna Stephen, \& Carter Perry. (2017). Commemorating the Enslaved Along Louisiana’s River Road. AAG Newsletter DOI:10.14437.

Ribeiro, Moura, Sequeira, Barbieri, \& Erdmann. (2015). Parents' and nurses' perceptions of Nursing care in neonatology - an integrative review. Revista de Enfermagem Referência, IV Série,4(1), 137-146.

Raffray, Semenic, Osorio Galeano, \& Ochoa Marín. (2014). Barriers and facilitators to preparing families with premature infants for discharge home from the neonatal unit. Perceptions of health care providers. Investigación y Educación en Enfermería, 32(3), 379-392.

Scherf, \& Reid. (2006). Going Home: What NICU Nurses Need to Know about Home Care. Neonatal Network, 25(6), 421-425.

Smith, Young, Pursley, McCormick, \& Zupancic. (2009). Are families prepared for discharge from the NICU? Journal of Perinatology, 29(9), 623-629.

Zamanzaheh\&Valizadeh.(2013). Mother's experiences of infant discharge in Iranian NICU :Culture Aqualitiative study.In Advances in Neonatal care .

Watts, \& Gardner. (2005). Nurses' perceptions of discharge planning. Nursing \& health sciences, 7(3), 175-183. 


\title{
إدراك وممارسات ممرضى الأطفال تجاه خروج حديثى الولادة من وحدات الرعاية المركزة

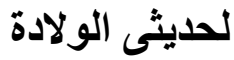

\author{
أ. د /أمل أحمد خليل، أ.م.د / منى إبراهيم أبوزيد،سيناء عبد الفتاح خطاب \\ أستاد تمريض الأطفال ـ كليه التمريض - جامعه بورسعبي،/ستاذ مساعد تمريض الأطفال - كليه التمريض- \\ جامعه بورسعبد، بكالوريوس تمريض جامعة المنصورة2002
}

\section{الخلاصة}

مقدمة:تعنبر رعاية تخطيط خروج الأطفال حديثي الو لادة اليوم من وحدات العناية المركزة لحديثي الو لادةمكونًا

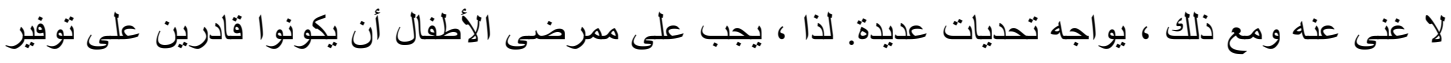
رعاية تمريضية فعالة وأن يكونوا على إدراك تام بدور هم في تحقيق الخروج الناجح للطفل من وحدة العناية المركزة لحديثي الو لادة ـ الههف من الدراسة: تهدف الدراسة الحالية إلى تقييم إدراك وممارسات ممرضى الأطفال تجاه خروج الأطفال حديثي الولادة من وحدات العناية المركزة لحديثي الولادة. مكان الدراسة: المستشفيات الحكومية في محافظة بورسعيد.تصميم البحث: تم استخدام التصميم الوصفيللدراسة الحالية. عينة البحث:تتكون عينة البحث من • 7 ممرضة أطفال في وحدات الرعاية المركزة لحديثي الولادة فيالمستشفيات الحكومية في محافظة بورسعيد. أدوات البحث: تم استخدام أداتين في هذه الدراسة وهما استبيان ممارسات

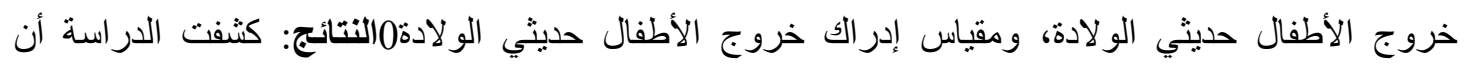
ممارسات خروجالأطفال حديثي الو لادة لجميع ممرضى الأطفال كانت ضعيفة، مثل عدم مشاركة الوالدين في رعاية الطفل في وحدة العناية المركزة لحديثي الولادة ، و عدم وجود طرق واضحة لتقييم تخطبط الخروج. بالاضافة الى أن هناك علاقات ذات دلالة إحصائية بين ممارسات ممرضى الأطفال و إدراك الممرضات تجاه خروج الأطفال حديثي الو لادة من وحدات العناية المركزة. الخلاصة: توجد علاقة ارتباطية ايجابية ذات دلالة احصائية بين ممارسات ممرضى الأطفال و إدراكهنجاه خروج الأطفال حديثي الولادة من وحدات العناية المركزة.التوصيات:توصي الدراسة ببرنامج تدريبي مستمر لممرضي الأطفال لتعزيز ادراكهم وتحسين مهار اتهوتجاه خروج الأطفال حديثي الو لادة من وحدات العناية المركزة.

الكلمات المرشدة: تخطيط الخروج ، عملية الخروج ، رعاية الخروج ، إدرالك الخروج ، ممارسات الخروج،

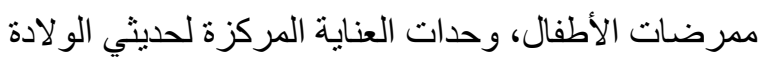

